\title{
The Response of Two Halophytic Species to Crude Oil-Contaminated Soil in the Northern Western Region of Egypt
}

\author{
Amal M. Abd-Elrahman \\ Botany and Microbiology Department, Faculty of Science, Alexandria University, Alexandria, Egypt
}

\begin{abstract}
A site that covers over 20 acres of coastal saline depression in the western Mediterranean coastal desert of Egypt (El-Hamra station, the main crude oil pipeline terminal in Alamein) is contaminated with petroleum. This area, prior to contamination by crude oil was dominated by different common halophytes. Atriplex halimus (L) and Arthrocnemum macrostachyum (Moric.) are now the most dominant species growing in this site. These species adapt themselves through different growth parameters, physiological and biochemical changes. Crude oil affects significantly on soil fertility and increasing $\mathrm{pH}$ (8.4). Importance value (IV), height and canopy diameter of the two studied species exhibited an increase in the polluted site. Organic metabolites such as fatty acids, antioxidant compounds and protein fractions in shoots of studied species which collected from the oil-contaminated and noncontaminated sites were examined. Fatty acid fractions exhibited the opposite performance especially the content of saturated C: 16 (palmitic), mono and di-unsaturated C18:1 (oleic) and C18:2 (linoleic) fatty acids as well as poly-unsaturated C18: 3 and C20: 3 (Omega -3 fatty acids). Antioxidant activity and most examined phenolic compounds were increased in A. macrostachyum which grow in a contaminated site. Protein fractions in A.halimus attained with enormous variations therefore, a Genomic Templet Stability (GTS \%) was lower than in A. macrostachyum under contamination. The biochemical and behavioral responses to oil pollution varied with the two different species may be according to the genetic make-up of individuals, which make the two studied species useful and effective tools for phytoremediation purposes.
\end{abstract}

Key words: Adaptation; Arthrocnemum macrostachyum; Atriplex halimus; Petroleum.

\section{INTRODUCTION}

Plants are always exposed to abiotic environmental stresses. Soil contaminants are main abiotic stress factors which caused great negative effect on overall plants' growth, metabolism and hence productivity and sustainability (Wani et al., 2018).

Ecological pollution with petroleum oil has been recognized as a serious problem affecting the biodiversity of the ecosystems in the impacted areas (Lin et al., 2002; Lawer et al., 2013). Crude oil is a complex mixture of hydrocarbons consisting of both aliphatic and aromatic structures and toxic in nature (AlHawas et al., 2012; Shukry et al., 2013).

The plant community in petroleum wastes impacted site usually disappears after several months, leaving high content of weathered hydrocarbons (Lin et al., 2005). After some time, revegetation by the appearance of supposed oil tolerant plant species occurs (Mendelssohn et al., 2002), and it has been hypothesized that revegetation in these crude oil contaminated sites is a result of ecological, biochemical and physiological adjustments of these plant species to the hydrocarbons existence (Merkl et al., 2004).

Nowadays, these environmental problems cause dangerous damages to soil micro flora and plants. Oil physical and chemical effects caused to change metabolism and growth of plants (Treutter 2006; Yan 2018). Therefore, they affect all plant morphological and physiological parameters, photosynthetic pigments (Han et al., 2016) and nutrient absorption (Rosso et al., 2005). Since, the plants are immovable; they must have different mechanisms depending on the plant species, oil type, amount and concentration for their survival and to make them resistant to adverse environments and keep their suitability (Zhang et al., 2007; Besalatpour et al., 2008).
Notably, the halophytic species; Atriplex halimus and Arthrocnemum macrostachyum are growing in a natural eco-system at Alamin saline depression where the soil is infused with crude oil. Therefore, the main objective of this study was to determine to what range the metabolites of the selected species influence their survival in an oil-contaminated environment.

\section{MATERIAL AND METHODS}

\section{Description of the studied sites}

The study site covers over 20 acres of coastal saline depression in the western Mediterranean coastal desert of Egypt (El-Hamra station, the main crude oil pipeline terminal in Alamein) is contaminated with crude oil as a result of activities from refineries, tanker and pipeline break-ups and oilfield blowouts, (Barakat et al., 2001). This site is located about $120 \mathrm{~km}$ west of Alexandria city between $30^{\circ} 80^{\prime}$ to $31^{\circ}$ North latitude and $29^{\circ} 30^{\prime}$ East longitudes (Figure 1). The area prior to contamination was dominated with different common halophyte species such as Limonastrum mono-petalum, Zygophyllum album, Arthrocnemum macro-stachyum, Suaeda prunosa and Salsola tetranda, (Ayyad and ElGhareeb 1982). Now, few species were found growing in this oil-contaminated site.

\section{Sample collection}

Aerial parts (shoots) form (3-10) individuals of the two-dominant species; Atriplex halimus and Arthrocnemum macrostachyum were selected randomly at each site (contaminated and non-contaminated) during winter 2017-2018. In the field, plant parts were carefully cleaned of the sand particles. The samples of plants and soil underneath $(0-30 \mathrm{~cm})$ were collected and then stored in plastic bags, brought to the laboratory shortly after collection and prepared for analysis. There were three independent replicates for plants and soil 
samples in each study site. The non-contaminated site is located about $10-20 \mathrm{Km}$ east of the con- terminated site in a natural saline depression habitat.

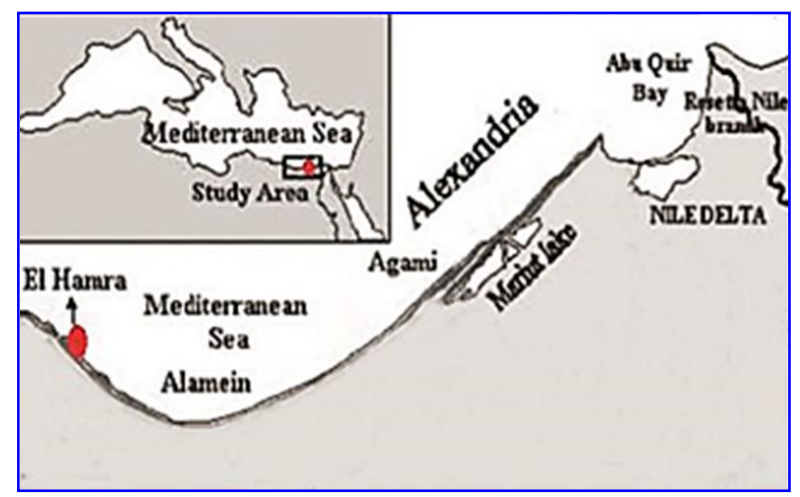

Figure (1): Location map of the study site in the Mediterranean coastal region is presented by circle (Frithy et al., 2004).

\section{Soil analysis}

Three soil samples were collected from each site from the depth ranged from $0-30 \mathrm{~cm}$. Soil texture was determined by the hydrometer method (Bouyoucos, 1962). Total organic matter was determined by wet oxidation according to Black (1965). Soil past extract was prepared according to Richards (1954) for estimation of $\mathrm{pH}$, electrical conductivity (EC). As well as soluble cations $\left(\mathrm{Ca}^{++}, \mathrm{Mg}^{++} \mathrm{Na}^{+}, \mathrm{K}^{+}\right.$, ) and anions $\left(\mathrm{CO}_{3}^{--}, \mathrm{HCO}_{3}^{-}, \mathrm{Cl}^{-}\right.$,). Calcium carbonate was assayed by calcimeter method according to Black (1965). Nitrogen was determined by kjeldahl method (Jackson, 1958) and total available phosphorus according to Trough and Meyer (1929).

\section{Vegetation analysis}

Absolute density, cover, and frequency were estimated in the field using quadrat and the transect method (Mannetje, 1978). Three stands (30 X $50 \mathrm{~m})$ were selected in each site and vegetation was surveyed using 25 quadrats in each stand and the cover determination was carried out along ten transects $(15 \mathrm{~m})$ in each stand. Relative density, relative frequency and relative cover were used to calculate the species importance value (IV) for the species existing in contaminated and noncontaminated sites. Life form spect-rum for each recorded species was identified according to Raunkiaer (1937). Plant nomenclature is according to Tackholm (1974); Boulos (2009). In addition, the height and canopy diameter of the studied species were also estimated.

\section{Plant analysis}

The plant samples from the aerial parts (shoots) of the two studied species were thoroughly washed with tap \& distilled water. Thereafter, dried in an oven at $60{ }^{\circ} \mathrm{C}$, then ground and prepare for analysis.

\section{Determination of the residual oil in plant and soil samples}

Plant /Soil samples weight were extracted with $150 \mathrm{ml}$ of high purity dichloromethane in Soxhlet for $16 \mathrm{~h}$. The extract was then evaporated in a reweighed beaker to determine the weight of the residue. The residue is reported as crude oil (Short et al., 1996).

\section{Fatty acids}

Lipid extraction of the plant material was carried out with methanol and chloroform (Harold et al., 1981) and then methanolysis of the total lipids was carried out with methano-sulphuric acid (Radwan 1978). Fatty acids were analyzed using gas chromatography model HP (Hewlett Packard) 6890. The column HP-INWAX (Cross-linked polyethylene glycol) $60 \mathrm{~m}, 0.25 \mathrm{~mm}$ ID, $0.25 \mu \mathrm{m}$ film thickness. An FID detector was used at 250 ${ }^{\circ} \mathrm{C}$ with an injection temperature $220^{\circ} \mathrm{C}$ the temperature program $4{ }^{\circ} \mathrm{C} / \mathrm{min}$ with used an initial temperature 140 ${ }^{\circ} \mathrm{C}$ for $5 \mathrm{~min}$. The fatty acids were identified by a comparison of the retention times with those of the standards. The double bond index (DBI) was calculated according to Campos et al., (2003).

Where: $\mathrm{DBI}=$

$[(\mathrm{C} 16: 1+\mathrm{C} 18: 1+2 \times \mathrm{C} 18: 2+3 \times \mathrm{C} 18: 3) /(\mathrm{C} 16: 0+\mathrm{C} 18: 0)]$.

\section{Phenolic compounds}

\section{Extraction of the Plant Material}

Aerial parts of both Atriplex halimus and Arthrocnemum macrostachyum from each site were dried and grinded. The dried powders $(0.5 \mathrm{~g})$ were extracted with methanol triplicate using sonication for $20 \mathrm{~min}$ each. The plant extracts were filtered and the solvents were evaporated under reduced pressure under vacuum using rotary evaporator at $50{ }^{\circ} \mathrm{C}$. The dried residues were weighed and then dissolved in methanol using $50 \mathrm{~mL}$ volumetric flask to prepare the sample solution.

\section{Phenolic Analysis by HPLC}

High Performance Liquid Chromatography (HPLC) was performed according to Boligon and Athayde (2014). An Agilent 1260 Infinity system (Germany) equipped with a multiple wavelength ultraviolet detector $(280 \mathrm{~nm}-320 \mathrm{~nm})$ performed the analysis of the phenolic compounds. The System consisted of quaternary gradient solvent pump to control the flow rate of the mobile phase (65 methanol: 35 water) and auto sampler for automatic injection, a vacuum degasser, a column oven $\left(40^{\circ} \mathrm{C}\right)$. Five microliters of each sample were injection onto the HPLC column using the auto sampler apparatus with a $100 \mu \mathrm{L}$ sample loop. The separation was performed on ZORBAX Eclipse plus C18 $(250 \times 4.6 \mathrm{Mm}$ id, $5 \mu \mathrm{m}$ particle size). Data were managed using HP Chemstation software.

\section{Antioxidant activity}

The antioxidant activity was evaluated by using the stable 2, 2-diphenyll-picrylhydrazy radical (DPPH) according to a modification of the method described by Wendy Brand Williams et al., (1995).

\section{Protein electrophoresis}

Sodium dodecyl sulphate polyacrylamide gel electrophoresis (SDS-PAGE) was applied for assessing the effect of crude oil contamination on protein content and its banding pattern in the aerial parts of the studied species according to Laemmli (1970). The bands 
produced by each sample were counted and the percentage of a Genomic Template Stability \% (GTS \%) was calculated (Cimino, 2006).

\section{Statistical analysis}

The significance of difference on the data of soil characters, height, and canopy of studied plants was calculated by Student's t- test, and values $p<0.05$ were considered to be significant, as well as the data of hydrocarbon compounds content in the aerial parts (shoots) and roots of studied species were subjected to standard one-way analysis of variance (ANOVA) test, all to assess the significance of variations of these variables under contaminated and non-contaminated conditions using IBM SPSS software package version conditions using IBM SPSS software package version
20.0 (Kirkpatrick and Feeney, 2013).

\section{RESULTS}

Crude oil contamination affected the soil physical and chemical properties (Table 1). The content of crude oil in contaminated soil was $20.29 \pm 8.94 \mathrm{mg} / \mathrm{g}$ dry weight but not detected in non-contaminated one. Soil $\mathrm{pH}$ (up to 8.4), organic matter \% and EC were significantly higher in contaminated than in non-contaminated soil, while total available phosphorus (AP) and nitrogen concentrations were significantly lower in the contaminated soil (Table1). Elements such as $\mathrm{K}^{+}, \mathrm{Mg}^{++}$, $\mathrm{Na}^{+}$and $\mathrm{Cl}^{-}$were higher in contaminated soil than in non-contaminated one while $\mathrm{Ca}^{++}$attained the opposite trend.

Table (1): Physical and chemical characteristics of soil and total content of petroleum hydrocarbon (TPHs) in contaminated and non-contaminated sites. Each value represents the mean $\pm \mathrm{SD}(\mathrm{N}=3)$.

\begin{tabular}{|c|c|c|c|c|}
\hline \multirow{2}{*}{ Parameters } & \multicolumn{2}{|c|}{ Site } & \multirow{2}{*}{$t$} & \multirow{2}{*}{$p$} \\
\hline & Contaminated & Non-Contaminated & & \\
\hline Texture & Sandy loam & Sandy loam & - & - \\
\hline $\mathbf{p H}$ & $8.40 \pm 0.20$ & $7.90 \pm 0.10$ & $3.873^{*}$ & $0.018^{*}$ \\
\hline $\mathrm{EC}(\mathrm{ds} / \mathrm{m})$ & $110.62 \pm 3.99$ & $73.32 \pm 2.39$ & $13.885^{*}$ & $<0.001^{*}$ \\
\hline Organic matter \% (OM) & $4.50 \pm 0.44$ & $0.85 \pm 0.03$ & $14.358^{*}$ & $0.005^{*}$ \\
\hline $\mathrm{CaCO}_{3}(\%)$ & $36.23 \pm 2.10$ & $41.91 \pm 2.40$ & $3.082^{*}$ & $0.037^{*}$ \\
\hline Total nitrogen $(\%)$ & $0.03 \pm 0.01$ & $0.06 \pm 0.01$ & $3.130^{*}$ & $0.035^{*}$ \\
\hline Available phosphorus (AP) (ppm) & $5.23 \pm 0.50$ & $8.06 \pm 0.77$ & $5.333^{*}$ & $0.006^{*}$ \\
\hline $\mathbf{K}^{+}(\mathbf{m e q} / \mathbf{L})$ & $46.30 \pm 3.36$ & $13.76 \pm 1.25$ & $15.727^{*}$ & $<0.001^{*}$ \\
\hline $\mathrm{Ca}^{++}(\operatorname{meq} / \mathrm{L})$ & $35.63 \pm 1.37$ & $65.58 \pm 2.51$ & $18.143^{*}$ & $<0.001^{*}$ \\
\hline $\operatorname{Mg}^{++}(\operatorname{meq} / \mathbf{L})$ & $631.21 \pm 16.69$ & $210.27 \pm 10.78$ & $36.702^{*}$ & $<0.001^{*}$ \\
\hline $\mathrm{Na}^{+}(\mathbf{m e q} / \mathbf{L})$ & $1225.41 \pm 14.83$ & $733.19 \pm 10.57$ & $46.818^{*}$ & $<0.001^{*}$ \\
\hline $\mathrm{HCO}_{3}^{-}(\mathrm{meq} / \mathrm{L})$ & $41.19 \pm 1.87$ & $40.59 \pm 1.85$ & 0.393 & 0.714 \\
\hline $\mathrm{Cl}^{-}(\mathbf{m e q} / \mathrm{L})$ & $1404.74 \pm 15.02$ & $857.77 \pm 8.20$ & $55.367^{*}$ & $<0.001^{*}$ \\
\hline $\mathrm{CO}_{3}^{--}$ & ND & ND & - & - \\
\hline TPHs (mg/g. dry soil) & $20.29 \pm 8.94$ & ND & - & - \\
\hline
\end{tabular}
ND, Not tested.

The vegetation characteristics of the two studied sites are represented in table 2. Species recorded IV was different between the contaminated and uncontaminated sites. The number of species recorded in the contaminated site was more than those recorded in noncontaminated one. Notably, A. macrostachyum was the most dominant species in contaminated site followed by Halocnemum strobilaceum and A.halimus, while Kochia indica, Phragmitis aus-trallis and Spergula fallax were individualized. In non-contaminated site, Halocnemum strobilaceum, A.macrostachyum and Limoniastrum monopetalum were the most dominant plants.

The height and the canopy diameter of the two studied species were the highest in the contaminated site compared with non-contaminated one (Table 3 ). The height of A.hilimus increased significantly more than two times in the contaminated site. However, the canopy diameter of A. macrostachyum also recorded a significant increase, more than two times, in the contaminated site.

Table (2): List of the plant species recorded in the study area with their families, life form, and its importance value.

\begin{tabular}{|c|c|c|c|c|}
\hline \multirow{2}{*}{ Plant species } & \multirow{2}{*}{ Family } & \multirow{2}{*}{ Life form } & \multicolumn{2}{|c|}{ 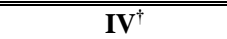 } \\
\hline & & & Con. & Non. \\
\hline Atriplex halimus (L.) & Chenopodiaceae & phanerophytes & 40.36 & 9.08 \\
\hline Arthrocnemum macrostachyu(Moric) & Chenopodiaceae & Phanerophytes & 148.91 & 89.22 \\
\hline Halocnemum strobilaceum (Pall.) & Chenopodiaceae & Phanerophytes & 53.99 & 134.96 \\
\hline Limoniastrum monopetalum (L.) Boiss & Plampagenaceae & Chamaephytes & 10.97 & 60.29 \\
\hline Zygophyllum album (L.) & Zygophyllaceae & Chamaephytes & 20.98 & 6.43 \\
\hline Kochia indica (Wight) & Chenopodiaceae & Therophyte & 4.15 & NR \\
\hline Phragmitis australis (Cav.) & Poaceae & Geophyte & 21.45 & NR \\
\hline Spergula fallax (Lowe) & Caryophyllaceae & Therophyte & 7.23 & NR \\
\hline
\end{tabular}

${ }^{\dagger}$ IV, Important Value; Con, contaminated site; Non., non-contaminated site; NR: not recorded. 

Table (3): The measured plant height and canopy diameter of the two studied species in the contaminated and non-contaminated sites. Each value represents the mean $\pm \mathrm{SD}(\mathrm{N}=3)$.

\begin{tabular}{lll}
\hline \hline Plant species & Plant Height $(\mathbf{c m})$ & Canopy diameter $(\mathbf{c m})$ \\
\hline Atriplex halimus (Con.) & $129.0 \pm 55.0$ & $724.0 \pm 213.9$ \\
Atriplex halimus (Non.) & $61.0 \pm 7.0$ & $406.7 \pm 75.1$ \\
$\boldsymbol{t}(\boldsymbol{p})$ & $\mathbf{2 . 7 2 7}^{*}\left(\mathbf{0 . 0 4 9}^{*}\right)$ & $\mathbf{2 . 4 1 5}(\mathbf{0 . 0 5 2})$ \\
Arthrocnemum macrostachyum (Con.) & $62.2 \pm 32.8$ & $238.2 \pm 91.8$ \\
Arthrocnemum macrostachyum (Non.) & $43.3 \pm 18.6$ & $84.1 \pm 41.3$ \\
$\boldsymbol{t}(\boldsymbol{p})$ & $\mathbf{1 . 5 8 3}(\mathbf{0 . 1 3 1})$ & $\mathbf{4 . 8 4 0 * *}^{*}(<\mathbf{0 . 0 0 1})$ \\
\hline \hline
\end{tabular}

$t$, Student's t-test; $p, p$-value for comparing between two sites.*: significantly at $p \leq 0.05$; **, highly significant at $p \leq 0.001$. Con, contaminated site; Non, non-contaminated site.

Table (4): The content of hydrocarbons compounds (mg/g dry wt.) in shoots and roots of the two studied species in contaminated and non-contaminated sites. Each value represents the mean $\pm \mathrm{SD}(\mathrm{N}=3)$.

\begin{tabular}{|c|c|c|c|c|c|c|}
\hline \multirow{2}{*}{ Plant species } & \multicolumn{2}{|c|}{ Shoots } & \multicolumn{2}{|c|}{ Roots } & \multirow{2}{*}{$\mathbf{F}$} & \multirow{2}{*}{$\boldsymbol{p}^{\dagger}$} \\
\hline & Con. & Non. & Con. & Non. & & \\
\hline Atriplex halimus & $36.28 \pm 3.20^{\mathrm{a}}$ & $20.23 \pm 2.14^{b}$ & $13.92 \pm 3.04^{b}$ & $6.86 \pm 0.34^{\mathrm{c}}$ & $78.178^{*}$ & $<0.001^{*}$ \\
\hline Arthrocnemum macrostachyum & $24.44 \pm 2.86^{\mathrm{a}}$ & $22.41 \pm 2.28^{\mathrm{a}}$ & $6.09 \pm 1.87^{b}$ & $5.98 \pm 0.19^{b}$ & $72.059^{*}$ & $<0.001^{*}$ \\
\hline
\end{tabular}

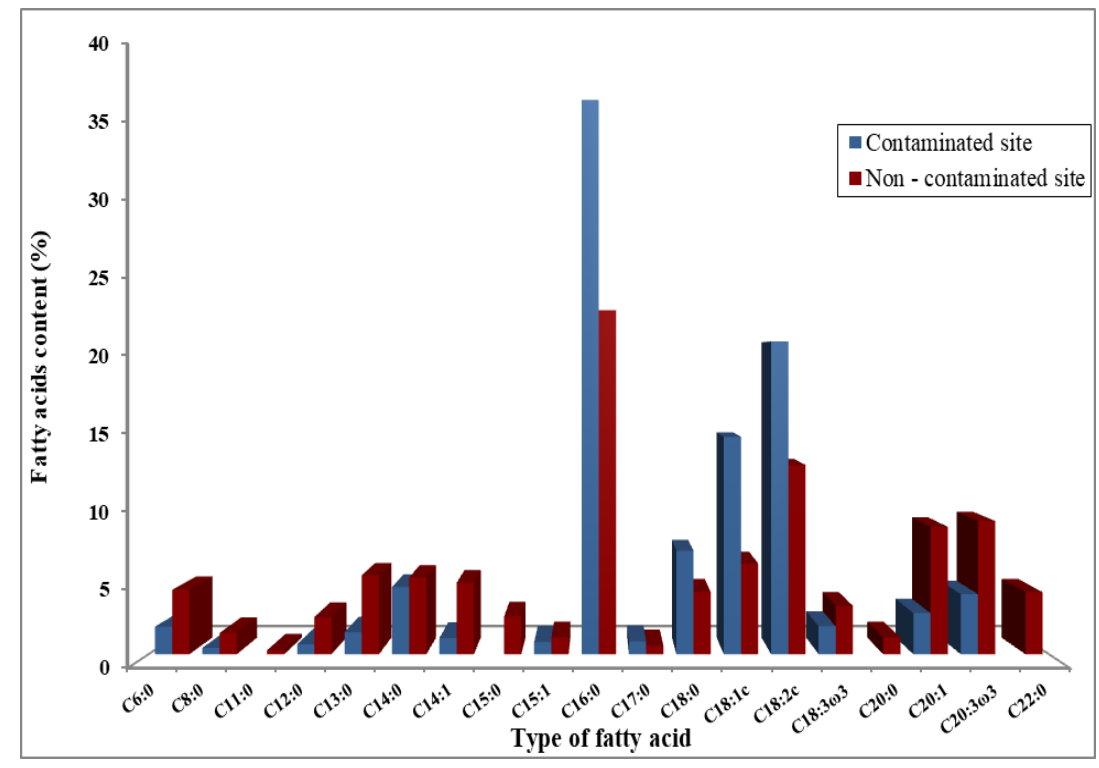

Figure (2): Fatty acid content, in percentage, of total fatty acids detected in A. halimus in contaminated and non-contaminated sites. The code indicates the number of double bonds. Relative content for $\mathrm{C} 11, \mathrm{C} 15, \mathrm{C} 20$ and $\mathrm{C} 22$ fatty acids in contaminated site were not detected.

Changes in the fatty acid composition of the two studied species are shown in figures $2 \& 3$. The total content of fatty acids in A. halimus (Figure 2) was higher than in A. macrostachyum in contaminated and non-contaminated sites. The content of fatty acids in A. halimus in the non-contaminated site was more than in contaminated site while the opposite was recorded in $A$. macrostachyum (Table 3 ). Fatty acid content as percentage of total fatty acids showed that Palmitic acid (C16:0) was the major saturated fatty acid in A. halimus which represent about $23.1 \%$ in non-contaminated site compared to $37.2 \%$ in contaminated site. Linoleic acid (C18:2) and oleic acid (C18:1) which represented 13\% and $6 \%$ in non-contaminated site and increased by $61 \%$ and $57 \%$ in contaminated one respectively. Monounsaturated (C20:1) and Poly-unsaturated (C20:3) and (C18:3) omega 3 fatty acids decreased due to contamination by $68 \%$ and $55 \%$ and $42.3 \%$ respectively. Four types of saturated fatty acids (C11:0, C15:0, C20:0, C22:0) in A. halimus disappeared in contaminated site. The ratio of total unsaturated to saturated fatty acids was calculated in order to explore 

any obvious effects on the degree of unsaturation for both species in the two sites (Table 5). Slightly or mostly no difference for this ratio in both sites of each species was recorded, while double bond index (DBI) of A. halimus was slightly more in non-contaminated site and of $A$. macrostachyum was slightly more in contaminated one (Table 5). Most fractions of fatty acids in A. macrostachyum were increased in contaminated site (Figure 3). The majority of fatty acids percentage were palmitic acid (C16: 0) followed by linoleic (C18: 2) and oleic (C18: 1) and which accounting $36 \%, 20.2 \%$ and $7.1 \%$ of the total fatty acids respectively in non-contaminated site and decreased in contaminated one by $29.7 \%, 41.6 \%$ and $67.6 \%$ respectively. Polyunsaturated (Omega - 3 fatty acids) C18: 3 and C20: 3 and saturated fatty acids C22:0 increased under contamination by petroleum oil by $146 \%$ for omega 3 fatty acids and $119 \%$ for the other. Two types of fatty acids appeared in the shoot of $A$. macrostachyum only in contaminated site (C8:0) and (C20:1).

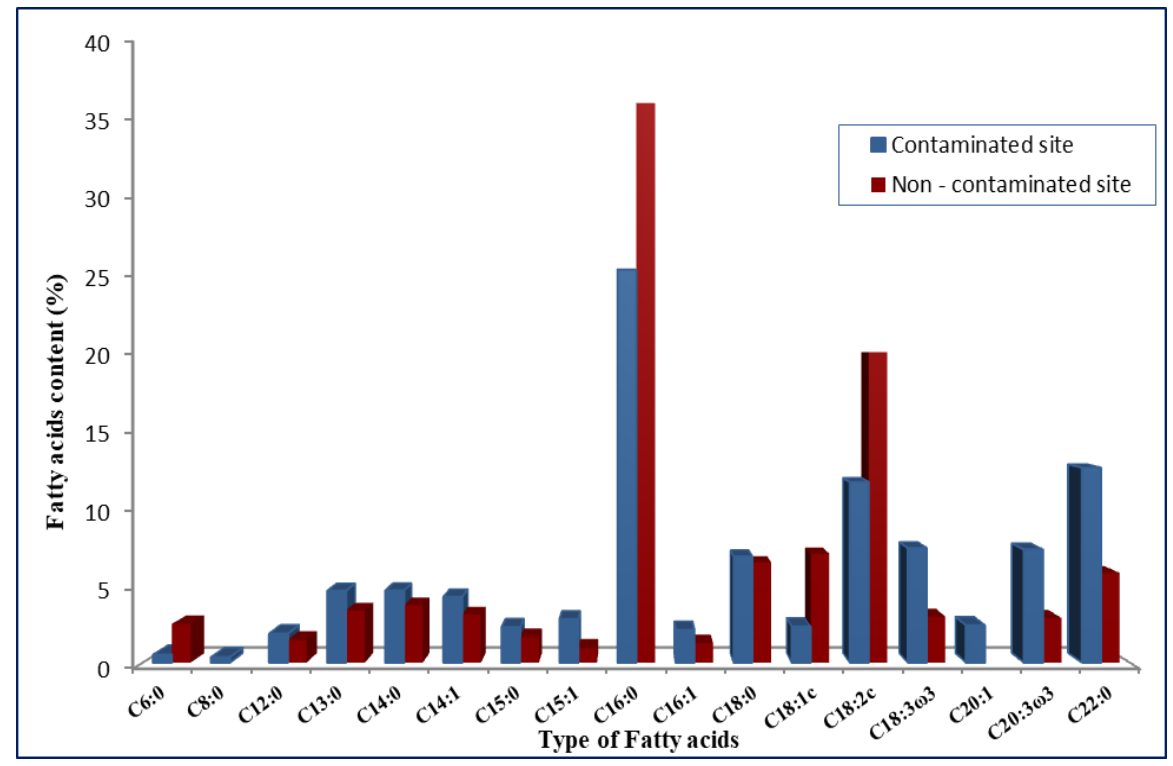

Figure (3): Fatty acid content, in percentage, of total fatty acids detected in A. macrostachyum in contaminated and non-contaminated sites. The code indicates the number of double bonds. Relative content for C11, C15, C20 and C22 fatty acids in contaminated site were not detected.

Table (5): Changes in fatty acid content (mg/100g of lipid) and double bond index (DBI) in the two studied species in contaminated and non-contaminated sites.

\begin{tabular}{|c|c|c|c|c|}
\hline \multirow{2}{*}{ Fatty acids } & \multicolumn{2}{|c|}{ Atriplex halimus } & \multicolumn{2}{|c|}{ Arthrocnemum macrostachyum } \\
\hline & Contaminated & Non-contaminated & Contaminated & Non-contaminated \\
\hline Total saturated fatty acids & 13.696 & 16.437 & 14.074 & 10.834 \\
\hline Total poly-unsaturated fatty acid & 6.831 & 7.487 & 6.279 & 4.596 \\
\hline Total content of fatty acids & 25.415 & 30.105 & 22.648 & 17.611 \\
\hline DBI & 1.4 & 1.52 & 1.55 & 1.35 \\
\hline
\end{tabular}

Phenolic compound (Rutin) content showed notably change between the two studied species in contaminated and non-contaminated sites (Table 6). Rutin in A.halimus decreased under contamination with crude oil, while in A. macrostachyum was increased. Concerning with the other phenolic compounds in A.halimus elagic, ferulic and chlorogenic increased in contaminated site and sinapic decreased while in $A$. macrostachyum all phenolic compounds increased with contamination except chromogenic. It is to be noted that antioxidant activity(DPPH inhibition \%) in both studied plants was always higher in contaminated site than in non-contaminated one (Table 6).

Sodium Dodecyl Sulphate Polyacrylamide Gel Electrophoresis (SDS-PAGE) as a biochemical marker technique, to evaluate pollution influence on A. halimus and A. macrostachyum collected from contaminated and non-contaminated sites (Plate1), showed different bands 
of protein profile which reveals the effect of hydrocarbons on the studied plants.

Generally, A. halimus expressed in many protein fractions after exposure to oil pollution comparing with $A$. macrostachyum, whereas the total number of bands in A. halimus was 22 and 19 in uncontaminated and contaminated site respectively. The new appeared bands (95, 60, 31, 29, 27, 21, 14, $12 \mathrm{KDa})$, disappeared bands (116, $99,72,51,38,30,28,21.5,20,16,13 \mathrm{KDa})$ and genome template stability (GTS \%) was $41 \%$ in contaminated site. In A. macrostachyum the total number of bands was 18 and 19 in uncontaminated and contaminated site respectively. The new appeared bands (95, 72, 54, $30 \mathrm{KDa})$, disappeared bands $(63,28,22$ $\mathrm{KDa})$ and (GTS \%) in contaminated site was $78 \%$.

Table (6): Phenolic compounds identified by HPLC of the methanolic extracts (mg/g.d.wt.) of the shoots of the two studied species and their antioxidant activity (DPPH inhibition \%).

\begin{tabular}{|c|c|c|c|c|}
\hline \multirow{2}{*}{ Constituent detected } & \multicolumn{2}{|c|}{ Atriplex halimus } & \multicolumn{2}{|c|}{ A. macrostachyum } \\
\hline & Con. & Non. & Con. & Non. \\
\hline Rutin & 8.2402 & 12.765 & 10.098 & 2.580 \\
\hline Elagic & 4.729 & 3.096 & 5.386 & 5.045 \\
\hline Ferulic & 0.703 & 0.380 & 1.891 & 0.676 \\
\hline Sinapic & 0.585 & 0.948 & 1.492 & 0.806 \\
\hline Chlorognic & 0.141 & 0.094 & 0.163 & 0.197 \\
\hline DPPH Inhibition (\%) & 92.05 & 63.58 & 91.18 & 85.55 \\
\hline
\end{tabular}

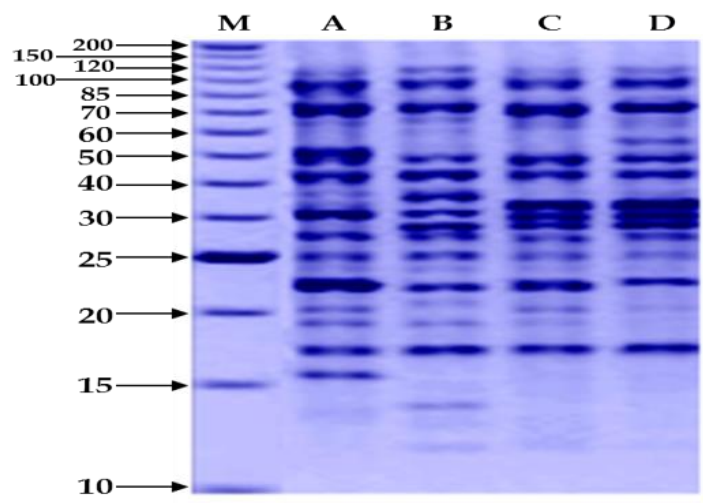

Plate (1): SDS-PAGE of Proteins isolated from leaves of $A$. halimus and $A$. macrostachyum in contaminated and uncontaminated sites; Lane A-A. halimus in non-contaminated site; Lane B-A. halimus in contaminated site; Lane C-A. macrostachyum in non- contaminated site; Lane D-A. macrostachyum in contaminated site; $\mathrm{M}$ - Protein marker.

\section{DISCUSSION}

In natural environments, plants respond to a combination of a biotic stresses like total petroleum hydrocarbons by different ways including morphological, physiological and even molecular response. Total petroleum hydrocarbons (TPHs) represent a group of serious pollutants of the environment with great impact on living organisms.

Regarding the physicochemical properties of contaminated soil, the crude oil contamination could potentially alkalinize the soils (8.4) and adversely affect soil fertility and physical properties, and hence cause deterioration to the soil (Wang et al., 2013). This may be explain why $\mathrm{CaCO}_{3}, \mathrm{TN}, \mathrm{PO}_{4}$, and $\mathrm{Ca}$ were lower in contaminated site compared to non- contaminated one which may be used by soil micro flora and explain the imbalance in $\mathrm{C} / \mathrm{N}$ ratio (Akunne, 2007).

Concerning the vegetation characters, the species height as well as crown cover were lower in contaminated than non - contaminated site, this may be due to the petroleum contamination reduce cell activity or even plant mortality (Lichtenthaler, 1996). Despite the ability of vegetation for adaptation and certain stress tolerance mechanisms, vegetation usually responds to sudden short-term or long-term stressors with reduced cell activity and reduced plant growth or even plant mortality. The stress factors vary in their intensity and duration which can cause damage to plant vegetation (Lichtenthaler, 1996). On the other hand, (Noomen et al., 2012) found that vegetation cover and species diversity are affected by hydrocarbon wastes. In the present study the IV, height and canopy diameter of the two studied species which indicate their biomass were more in contaminated site than in non-contaminated one. These results may be due to species tolerant to the determined content of hydrocarbons $(20.29 \mathrm{mg} / \mathrm{g}$ d.wt. \pm 8.94 ) in the contaminated soil. (Robson et al., 2004) showed that hydrocarbon pollution caused a decrease in vegetation cover and species richness, while some species were found to be tolerant. IV and richness are different between contaminated and noncontaminated site may be due to the variation between species abilities to tolerate crude oil (Racine, 1994), soil disturbance (Wali, 1999), low fertility (Wilson and Tilman 1991), difficult in the consumption of water and mineral salts from the soil, and also interruptions a number of metabolic processes (Rusin et al., 2015).

Organic molecules from crude oil can penetrate living plants through their roots and leaves from where the hydrocarbon compounds can be transported into the plant vascular system and intercellular spaces leading to cell and tissue damage, this effect depends on the type and amount of oil and the plant species (Baker, 1970).

The regulation of fatty acid biosynthesis may be an important means of controlling the membrane fatty acid unsaturation, contributing to the plant adaptation (Chaffai et al., 2009). Fatty acids are crucial components of cellular membranes, suberin, and cutin waxes that provide structural barriers to the environment (Beisson et al., 2007). The fatty acids of the two studied species were examined in response to crude oil pollution exhibit the opposite performance to each other. Whereas, in A. halimus most saturated fatty acid fractions and unsaturated fatty acids decreased especially (C20:3 and C18: 3) omega 3. This may be a result of free radical mediated oxidation of triple bonds. These highly reactive free radicals have strong affinities for the cell membrane (Hussein and Norman 2002). Also, the content of saturated (palmitic) and unsaturated (oleic and linolenic acid) increased under oil contamination. Carla and Maria (2018) stated that palmitic acid (C16:0) is building blocks for numerous regulations of membrane fluidity. Vereshchagin et al. (1985); Shayakh et al., (1990) stated that, linolenic and 
palmitic acids inherent to plant tissues under cold stress, these acids are believed to allow the cell adapt itself under adverse conditions at the expense of a rise in membrane fluidity and that is why it's absolute and relative level in the tissue rises. This unsaturated fatty acid (C18:3) may be maintaining membrane permeability (Badea and Basu 2009). In $A$. macrostachyum exhibit the opposite trend, increase of most saturated fatty acid fractions and unsaturated fatty acids especially (C20:3 and C18: 3) omega three. Also, the content of palmitic, unsaturated (oleic, linolenic and myristoleic acid) decreased under oil contamination. Anttonen et al., (1995) reported an increase in saturated fatty acids such as myristic, with a significant reduction in unsaturated fatty acids such as linolenic acid in ozone-exposed Aleppo pine (P. halepensis Mill.). This suggestion may be supported by the lower ratios of unsaturated to saturated fatty acids in A. macrostachyum growing at the contaminated site of the present study. The increase in DBI was probably due to a higher C18: 3 percentages and to a decrease in the more saturated fatty acids in the newly synthesized lipids. It may also depend on compositional changes resulting from lipid turnover (Campos et al., 2003).

Plant organisms being devoid of motility and immune system; have elaborated alternative defines strategies, involving the enormous variety of secondary metabolites (phenolic compounds) as tools to overcome stress constraints, adapt to the changing environment and survive (Vasconsuelo and Boland 2007). Secondary metabolites are compounds that are not necessary for an organism to live, but play a role in the interaction of the organism with its environment. These compounds are often involved in plants protection against biotic or abiotic stresses. Secondary metabolites are from different metabolites families that can be highly inducible in response to stresses (Pagare et al., 2015).

In the present study secondary metabolites mostly increased in contaminated site especially in A. macrostachyum. Ramakrishna and Ravishankar (2011) stated that the accumulation of such metabolites often occurs in plants subjected to stresses including various indicator molecules.

Most environmental stresses are affecting the production of active oxygen species in plants, causing oxidative stress (Hendry 1994 and Bartosz 1997). Also, there is growing evidence that in plants subjected to environmental stress the balance between the production of activated oxygen species and the activity of antioxidant is upset, which often results in oxidative damage (Smirnoff 1993; Karpinski et al., 1997). DPPH inhibition which represent the antioxidant activity of the two studied plants showed great values in contaminated site compared with uncontaminated one this may be due to the increase in most studied phenolic compounds under oil pollution (Elagic, Ferulic and chlorogenic in A.halimus) but (rutin, Ferulic and sinapic in A. macrostachyum). These are potential antioxidants and may work as ROS-scavenging compounds (Olga et al., 2003). Moreover, it has been shown recently that phenolic compounds can be involved in the hydrogen peroxide scavenging cascade in plant cells (Takahama and Oniki, 1997).

Proteins are compounds of fundamental importance for all functions in the cell (Dose, 1980). It is well known that alteration of gene expression is always involved in formulating plants for survival under stress. Protein variation is an essential part of plant response to environmental stress as well as for adaptation to environmental conditions (Vierstra, 1993; Hieng et al., 2004). The adaptation of protein biosynthesis and its structure under ecological stress factors such as chemical pollutants are of particular interest, frequently act together and trigger adaptive and protective mechanisms (Vinocur and Altman, 2005). One of the most important mechanisms involved in the cell protection against stress is the induction of de novo synthesis of a set of proteins (Kermode, 1997), these set of proteins were newly synthesized under drought stress conditions. In the present study, protein fractions in $A$. halimus attained with enormous variations (appearance and disappearance bands) therefore, GTS\% was lower than in A. macrostachyum under oil contamination. The synthesis of new protein fractions with different intensity revealed that the important role of protein in the resistance to stress imposed by crude oil. Tardieu (2013) stated that the physiological and behavioural responses to environmental condition depend on the genetic make-up of individuals which varied for expression and activity levels also plant species, oil kind, amount and concentration, exposure times and environmental condition (Zhang et al., 2007; Besalatpoor, 2008).

The studied species are growing abundantly and tolerant to crude oil pollution which may make them a useful tool for phytoremediation purposes. These results agree with (Malgorzata et al., 2017) who found that Lotus corniculatus L. and Oenothera biennis L. can be used as a phytoremediator species of polluted soil with petroleum hydrocarbons. The present study will show more promise for detailed studies and applications.

\section{REFERENCES}

AKUNNE, I. 2007. Effects of Oil Spillage on Farm Land (A Case Study of Uroboh)," Department of Agricultural and Bioresources Engineering, University of Nigenia., Nsukka, Nigeria, BEng Project Thesis.

AL-HAWAS, G.H.S, W.M. SUKRY, M.M. AZZOZ, AND R.M.S AL-MOAIK. 2012. The effect of sublethal concentrations of crude oil on the metabolism of Jojoba (Simmodsia chinensis) seedlings. Int Res J Plant Sci 3 (4): 54-62.

ANTTONEN, S., J. HERRANEN, P. PEURA, AND L.KARENLAMPI. 1995. Fatty acids and ultrastructure of ozone-exposed Aleppo Pine (Pinushalepensis Mill.) needles. Environ Pollut. 87: 235-42.

AYYAD, M.A., AND R. EL-GHAREEB. 1982. Salt marsh vegetation of the western Mediterranean desert of Egypt. Vegetatio 49: 3-19.

BADEA, C., AND S.K. BASU. 2009. The effect of low 
temperature on metabolism of membrane lipids in plants and associated gene expression. Plant Omics J. 2: 78-84.

BAKER J.M. 1970. The effects of oil on plants. Environmental Pollution. 1 : 27-44.

BARAKAT A.O., Q. YAORONG, K. MOONKO, AND M.C. KENNICUTT. 2001. Chemical characterization of naturally weathered oil residues in arid terrestrial environment in Al-Alamein, Egypt. Environ Int. 27: 291- 310.

BARTOSZ, G. 1997. Oxidative stress in plants. Acta Physiol. Plant, 19: 47-64.

BEISSON F., Y. LI, G. BONAVENTURE, M. POLLARD, AND J.B. OHLROGGE. 2007. The acyl transferase GPAT5 is required for the synthesis of suberin in seed coat and root of Arabidopsis. Plant Cell 19: 351-368.

BESALATPOUR AA, HAJABBASI MA, KHOSHGOFTARMANESH AH \& AFYUNI M. 2008. Remediation of petroleum contaminated soils around the Tehran oil refinery using Phytostimulation method, J. Agric.Sci. Natur. Resour., 44: 13-23

BLACK, C.A. 1965. Methods of soil analysis. Chemical and Microbiological Properties Part İ İ. Amer.Soc. Agric. Inc.pp.1044.

BOLIGON, A., AND M. ATHAYDE. 2014. Importance of HPLC of Plants Extracts. Austin Chromatography, Mini Review, 3: 1-2.

BOULOS, L. 2009. Flora of Egypt: Checklist, Revised Annotated ed. Al Hadara Publishing, Cairo, p. 410.

BOUYOUCOS, G.J. 1962. Hydrometer Method Improved for Making Particle Size Analysis of Soils. Agronomy Journal, 54: 464-465.

CAMPOS, S.P., V. QUARTIN, J.C. RAMALHO, AND M.A. NUNES. 2003. Electrolyte leakage and lipid degradation account for cold sensitivity in leaves of Coffea sp plants. J. Plant Physiol 160 (3): 283- 292.

CARLA, C.C.R. DE CARVALHO, AND M. J. CARAMUJO. 2018. The Various Roles of Fatty Acids. Molecules 23 (10): 2583.

CHAFFAI, R., T.N. SEYBOU, B. MARZOUK, AND E. EL- FERJANI. 2009. A comparative analysis of fatty acid composition of root and shoot lipids in Zea mays under copper and cadmium stress. Acta Biologica Hungarica 60 (1): 109-125.

CIMINO, M.C. 2006. Comparative overview of current international strategies and guidelines for genetic toxicology testing for regulatory purposes. Environmental and Molecular Mutagenesis Journal, 7: 362390.

DOSE, K. 1980. Biochemie. - Springer Berlin, Heidelberg, New York.

FRITHY, O.E., M.M. ISKANDER, AND A.A. BADR. 2004. Effect of shoreline and bedrock irregularities on the morphodynamics of the Alexandria cell, Egypt. Geo-Marlett. 24: 195-211.

HAROLD, E., S. K. RONALD, AND S. RONALD. 1981. Pearson's chemical analysis of foods / 8th ed. Edinburgh; New York: Churchill Livingstone. 591p.
HAN, G., B.X.CUI, X. X. ZHANG, AND K.R. LI. 2016. The effects of petroleum- contaminated soil on photosynthesis of Amorpha fruticosa seedlings. Int. J. Environ. Sci. Technol. 13: 23832392.

HENDRY, G.A.F. 1994. Oxygen and environmental stress in plants: an evolutionary context. Proc. Roy. Soc. Edinburgh 102B, 155-165.

HIENG, B., K. UGRINOVICH, J. SUSTARVOZLICH, AND M. KIDRIC. 2004. Different classes of proteases are involved in the response to drought of Phaseolus vulgaris cultivars differing in sensitivity. Journal of Plant Physiology 161: 519530.

HUSSEIN, S.H., AND T. NORMAN. 2002. Phytomonitoring the unique colonization of oilcontaminated saline environment by Limoniastrum monopetalum (L.) Boiss in Egypt. Environment International 28: 127-135.

JACKSON, M. L.1958: Soil chemical analysis. Verlag: Prentice Hall, Inc., Englewood Cliffs, N.J. p. 521.

KARPINSKI, S., C. ESCOBAR, B. KARPINSKA, G. CREISSEN, AND P.M. MULLINEAUX. 1997. Photosynthe1ic electron transport regulates the expression of cytosolic ascorbate peroxidase genes in Arabidopsis during excess light. Plant Cell, 9: 627-640.

KERMODE, A.R. 1997. Approaches to elucidate the basic of desiccation tolerance in seeds. Seed Sci. Res. 7: 75-95.

KIRKPATRICK, L.A., AND B.C. FEENEY. 2013. A simple guide to IBM SPSS statistics for version 20.0. Student ed. Belmont, Calif.: Wadsworth, Cengage Learning.

LAEMMLI, U.K. 1970. Cleavage of structural proteins during the assembly of bacteriophage T4. Nature Publishing Group, 277: 680-684.

LAWER, E.A., B.N. BAATUUWIE, K. OCHIREBOADU, AND A.W. JASPER. 2013. Preliminary assessment of the effects of anthropogenic activities on vegetation cover and natural regeneration in a moist semi-deciduous forest of Ghana. Int J Ecosys 3: $148-156$.

LICHTENTHALER, H.K. 1996. Vegetation Stress: an Introduction to the Stress Concept in Plants. Journal of Plant Physiology. 148 (1-2): 4-14.

LIN, Q., I.A. MENDELSSOHN, N.P. BRYNER, AND W.D. WALTON. 2005. Insitu burning of oil in

Coastal marshes, 1: Vegetation recovery and soil tempeerature as a function of water depth, oil type and marsh type. Environ Sci Technol 39: 1848-1854.

LIN Q., I.A. MENDELSSOHN, K. CARNEY, N.P. BRYNER, AND W.D. WALTON. 2002. Salt marsh recovery and oil spill remediation after in-situ burning: Effect of water depth and burn duration. Environ Sci Technol 36: 576-581.

MALGORZATA, P., C. BARBARA, T. SOFIE, V. JACO, AND P. ZOFIA. 2017. Hydrocarbon degradation potential and plant growth-promoting activity of culturable endophytic bacteria of Lotus corniculatus and Oenothera biennisfrom a long-term 
polluted site.Environ Sci Pollut Res Int. 24 (24): 19640-19652.

MANNETJE, L. 1978. Measurement of Grassland Vegetation and Animal Production. Commonwealth Agricultural Bureau,Bulletin 52, Hurley, Berkshire, England, 260.

MENDELSSOHN, I.A., Q. LIN, N.P. BRYNER, W.D. WALTON, W.H. TWILLEY, AND J.V. MULLIN. 2002. In-Situ oil burning in the marshland environment- recovery and regrowth of Spartina alterniflora, Spartina patens, and Sagittaria lancifolia plants. In: Proceedings of the Twenty-Fifth artic and Marine Oil Spill Program Technical Seminar: Environment Canada. 785-802.

MERKL, N., R. SCHULTZE-KRAFT, AND C. INFANTE. 2004. Phytoremediation of petroleumcontaminated soils in the tropic's preliminary assessment of the potential of species from eastern Venezuela. J Appl Bot Food Qual 78: 185-192.

NOOMEN, M.F., H.M.A. VAN DER WERFF, AND F.D. VAN DER MEER. 2012. Spectral and spatial indicators of botanical changes caused by long-term hydrocarbon seepage. Ecological Informatics. 8: 5564.

OLGA, B., V. EIJA, AND V.F. KURT. 2003. Antioxidants, oxidative damage and oxygen deprivation stress: a review. Annals of Botany, 91: 179-194.

PAGARE, S., B. MANILA, T. NIRAJ, P. SONAL, AND Y.K. BANSAL1. 2015. Secondary Metabolites of Plants and their Role: Overview Current Trends in Biotechnology and Pharmacy Vol. 9 (3): 293-304.

RACINE, C.H. 1994. Long-term recovery of vegetation on two experimental crude oil spills in interior Alaska black spruce taiga. Can. J. Bot. 72: 11711177.

RADWAN, S.S. 1978. Coupling of two dimensional thin layer chromatography with GC for the quantitative analysis of lipid classes and their constituents' fatty acids J.Chrom. Science 16: 538542.

RAMAKRISHNA, A. AND G.A. RAVISHANKAR 2011. Influence of abiotic stress signals on secondary metabolites in plants Plant Signal Behav. Nov 1; 6 (11): 1720-1731.

RAUNKIAER, C. 1937. Plant life forms. Clarendon, Oxford. 104 pp.RICHARDS, L.A. 1954. Diagnosis and improvement of saline and alkali soils. Agric.Res. Service, Agric. U.S. Dept. Agric., Agriculture Handbook No. 60.US Government Printing Office, Washington, D.C.204-02.

ROBSON, D.B., J.D. KNIGHT, R.E. FARRELL, AND J.J. GERMIDA. 2004. Natural revegetation of hydrocarbon-contaminated soil in semi-arid grasslands. Canadian Journal of Botany. 82 (1): 22 30.

ROSSO, P.H., J.C. PUSHNIK, M.L. LAY, AND S. USTIN. 2005. Reflectance properties and physiological responses of Salicornia virginica to heavy metal and petroleum contamination, Journal of Environmental Pollution, 137: 241-252.
RUSIN, M., G. JANINA, AND N. ALEKSANDRA 2015. The Effect of Petroleum-Derived Substances on the Growth and Chemical Composition of Vicia faba L. Pol. J. Environ. Stud. Vol. 24, No. 5. 2157 2166.

SHAYAKHMETOVA, I.S.H., TRUNOVA, T.I., TSYDENDAMBAEV, V.D., AND A.G. VERESHCHAGIN. 1990. The role of lipids in cell membranes of cryogenic hardening leaves and tillering nodes in winter wheat, Sov. Plant Phy-siol., vol. 37: 1186-1195.

SHORT, W.J., T.J. JACKSON, M.L. LARSEN, T.L. WADE. 1996. Analytical methods used for the analysis of hydrocarbons in crude oil, tissues, sediments, and seawater collected for the natural resources damage assessment of the Exxon Valdez oil spill. Am Fish Soc Symp 18: 481-493 .

SHUKRY, W.M., G.H.S. AL-HAWAS, R.M.S. ALMOAIKAL, AND M.A. EL-BENDARY. 2013. Effect of petroleum crude oil on mineral nutrient elements, soil properties and bacterial biomass of rhizosphere of jojoba. Br J Environ Clim Change 3 (1): 103-118.

SMIRNOFF, N. 1993. The role of active oxygen in the response of plants to water deficit and desiccation. New Phyto. 1., 125: 27-58.

TACKHOLM, V. 1974. Students' flora of Egypt, 2nd. Cairo.

TARDIEU, F. 2013. Plant response to environmental conditions: assessing potential production, water demand, and negative effects of water deficit. Front Physiol. 4- 17.

TAKAHAMA, U., AND T. ONIKI. 1997. A peroxidase/ phenolics/ ascorbate system can scavenge hydrogen peroxide in plant cells. Physiologia Plant., 101: 845-852.

TREUTTER, D. 2006. Significance of flavonoids in plant resistance: a review, Environmental Chemistry Letters, 4 (3): 147-157.

TROUGH, E., AND A.H. MEYER. 1929. Improvements inthe Deniges colorimetric method for phosphorus and arsenic. Ing. Eng. Chem. Analy. Ed. 1: 136-139.

VASCONSUELO, A. AND R. BOLAND. 2007. Molecular aspects of the early stages of elicitation of secondary metabolites in plants, Plant Sci., 172: 861-875

VERESHCHAGIN, A.G., N.L. LEBEDEVA, A.V. ZHUKOV, AND L.P. CHEL'TSOVA. 1985. Content and composition of the esterified fatty acids in mitochondria of wheat seedlings after seed vernalization, Sov. Plant Physiol., 32: 361-367.

VIERSTRA, R.D. 1993. Protein degradation in plants. Annual Review of Plant Physiology and Plant Molecular Biology 44: 385-410.

VINOCUR, B., AND A. ALTMAN. 2005. Recent advances in engineering plant tolerance to abiotic stress:and limitation. Current Opinion in Biotechnology, 16: 123-132.

WALI, M.K. 1999. Ecological succession and the rehabilitation of disturbed terrestrial ecosystems. Plant Soil, 213: 195-220. 
WANI, W., K. Z. MASOODI, ABBU- ZAID, H. WANI, F. SHAH, V.S MEENA, S.A. WANI, A .W. SHAFIQ, AND K.A. MOSA. 2018. Engineering plants for heavy metal stress tolerance. Rendiconti Lincei. Scienze Fisiche e Naturali 29: 709-723. https://doi.org/10.1007/s12210-018-0702-y.

WANG, Y., J. FENG, Q. LIN, X. LYU, X. WANG, G. WANG. 2013. Effects of crude oil contamination on soil physical and chemical properties in Momoge Wetland of China. Chinese Geographical Science, 23 (6): 708-715.

WILSON, S.D., AND D. TILMAN. 1991. Interactive effects of fertilization and disturbance on community structure and resource availability in an oldfield plant community. Oecologia, 88: 61-71.
WENDY BRAND-WILLIAMS, W. M.E. CUVELIER, AND C. BERSET. 1995. Use of a free radical method to evaluate antioxidant activity. LWT-Food Science and Technology, 28: 25-30.

YAN, X., S. GAOQI, AND W. SHUGUANG. 2018.

Effects of oil pollution stress on the growth status of ryegrass. Earth and Environmental Science 170:052033. doi :10.1088/1755-1315/170/5/052033.

ZHANG, C.G., K.K. LEUNG, Y.S. WONG, AND N.F.Y. TAM. 2007. Germination, growth and physicological responses of mangrove plant (Bruguiera gymnorrhiza) to lubricating oil pollution, Journal of Environmental and Experimental Botany, 60: 127136.

\title{
استجابة نوعان من النباتات الملحية للتربة الملوثة بالزيت الخام في المنطقة الثمالية الغربية لمصر
}

\author{
أمال محمد محمد عبد الرحمن \\ كلية العلوم- قسم النبات و الميكروبيولوجئ فيد الرجمن جامعة الاسكندرية \\ الملخص العربــي
}

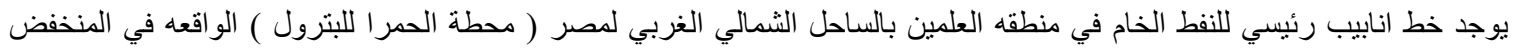

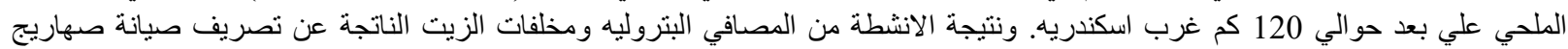

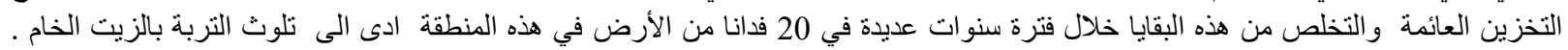

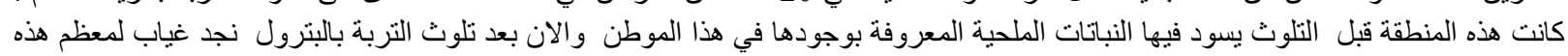

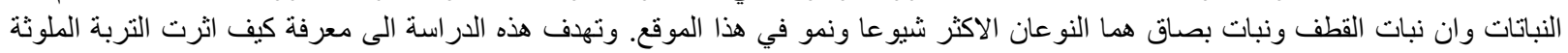

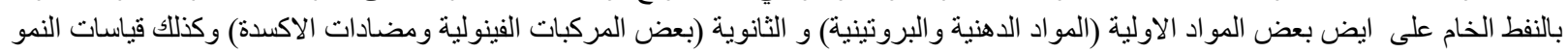

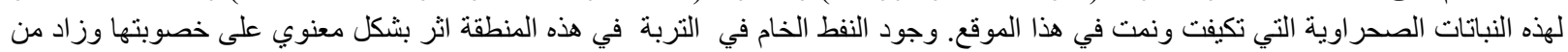

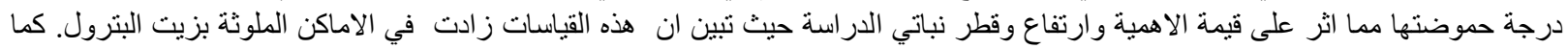

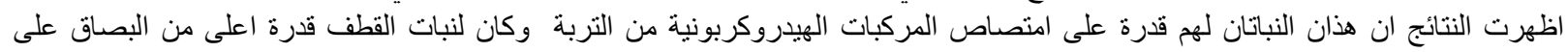

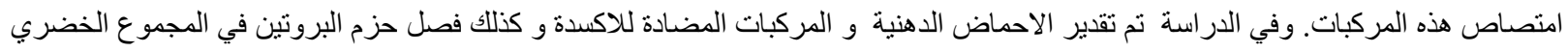

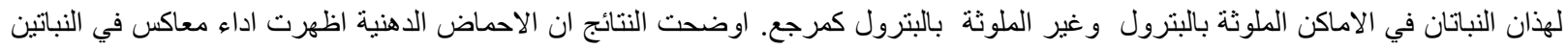

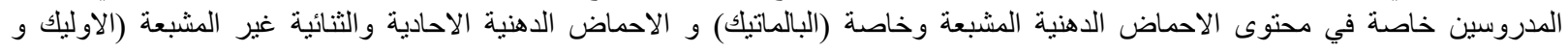

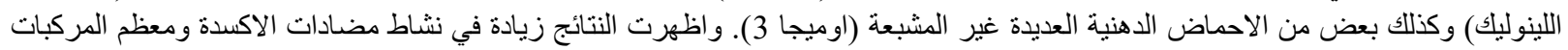

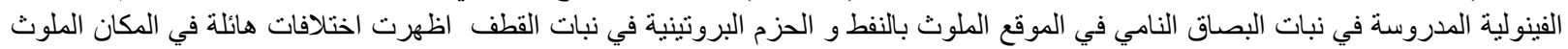

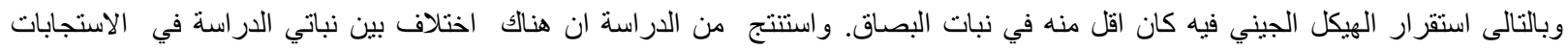

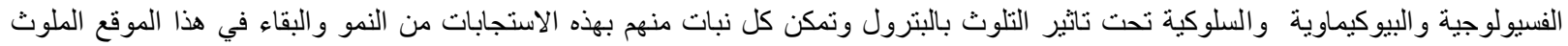

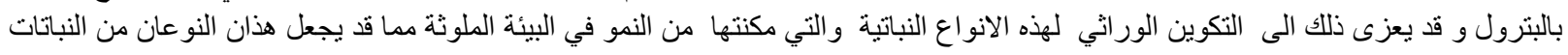

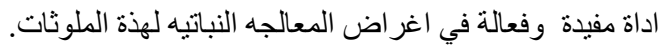

